\title{
RESPONSIVENESS OF ELECTRICITY GENERATION TOWARDS PRICE LEVEL: AN EMPIRICAL INVESTIGATION FROM PAKISTAN
}

\author{
HAFIZ SAQIB MEHMOOD NAJMI \\ District Teacher Educator, \\ Directorate of Staff Development, Punjab, Lahore. \\ FURRUKH BASHIR \\ Lecturer of Economics, \\ The Islamia University of Bahawalpur, Pakistan. \\ Bahawalnagar Campus \\ Email: farrukh.bashir@iub.edu.pk \\ FARIDA NADEEM \\ M.Sc. Scholar of Economics, \\ The Islamia University of Bahawalpur, Pakistan. \\ Bahawalnagar Campus
}

\begin{abstract}
The purpose of this study is to explore the effect of Electricity Generation on Price level of Pakistan's Economy during period from 1981 to 2013. ARDL estimation technique is followed for reliable long run and short run estimates of the model. For elasticities of Price level, all variables are transformed into natural log form. Electricity Generation is discovered as declining price level while exports, money supply and external debt are increasing price level of Pakistan.
\end{abstract}

Keywords: Price Level, Electricity Generation, ARDL, Money Supply, Exports, External Debt

JEL Classification Codes: C32, E31, E51, H63, O13, Q43

\section{INTRODUCTION}

Inflation shows a continuous rise in the general price level of the economy because it affects purchasing power of the society. According to Demand Pull Inflation theory, inflation happens in the economy when aggregate demand is exceeded in comparison with aggregate supply. Decrease in aggregate supply due to supply shocks is stated by Cost Push Inflation theory. Monetary theory of inflation states money growth as main cause of 
inflation. According to Quantity theory of money, inflation is directly proportional to money supply.

The economy of Pakistan is seriously facing the problem of Energy Crisis in which poor power generation is raising political instability, lacking in efficient production, higher external debt, instability in exchange rate, trade deficit etc. and ultimately it is influencing price level. Sarker et al. (2010) examined nexus between electricity Generation and economic growth in Bangladesh using time series data from 1973 to 2006. Adom (2011) explained causality between electricity consumption and economic growth using time series data from 1971 to 2008. Masduzzaman (2012) studied Electricity consumption and Economic growth in Bangladesh.

Considering importance, objective of the study is to explore the influence of electricity generation on price level of Pakistan. The study is organized as review of the literature is furnished in $2^{\text {nd }}$ section, data and models are specified in section 3 , empirical findings are provided in section four, $5^{\text {th }}$ section concludes the whole resume and references are provided at the end.

\section{LITERATURE REVIEW}

Several studies on the issue of inflation and electricity consumption have been accomplished and few of them are summarized in this section. Morimoto and Hope (2004) showed that current as well as past changes in electricity supply had a significant impact on the changes in real gross domestic product in Sri Lanka and gross domestic product (time-2) had negative relation.

Laryea and Sumaila (2001) conducted a study to explore determinants of inflation. Time series data was collected from 1961 to 1998 . Gross domestic product, exchange rate, and money supply had positive relationship with inflation. Aslan et al. (2013) illustrated feedback hypothesis between energy and economic growth for 47 US states over the period 1997 - 2009. Lim and Papi (1997) discovered determinants of inflation in Turkey by analyzing price determination within framework of a multi - sector macroeconomic model during 1970 - 95. The study concluded monetary variables playing a central role in the inflationary process.

Razzaqi et al. (2007) collected time series data from 1980 to 2007 to explore the dynamic relationship between energy and economic growth. The results concluded positive 
association of energy use with gross domestic product for D8 countries. Bayo (2009) empirically analyzed determinants of inflation using time series data (1981 - 2003). The result showed fiscal deficit, money supply, interest rate and exchange rates as significantly and positively contributing in inflation while exchange rate had negative impact on inflation.

Khan et al. (2007) explained adaptive expectation phenomenon affecting overall Consumer price index, particularly food prices. Moreover, Private sector borrowing, exchange rate depreciation and adaptive expectation were revealed main factors behind this growth in consumer prices using time series data from 1972 to 2006. Domac and Elbirt (1998) investigated the determinants of Inflation in Albania employing granger causality test using disaggregated data and indicated that money supply and exchange rate had an important role in consumer price index.

Shahbaz and Feridum (2012) provided empirical evidence of electricity consumption and economic growth using time series data from 1971 to 2008 and conducted positive relationship between gross domestic product and Electricity consumption in Pakistan. Bayraktutan et al. (2011) utilized Panel unit root and Co-integration to examine relationship between renewable electricity generation and economic growth using time series data from 1980 to 2010 and revealed bidirectional causal relationship between economic development and renewable energy production.

Bashir et al. (2011) analyzed positive relationship of broad money, gross domestic product, imports of goods \& services, government expenditure and revenue with inflation in Pakistan for the period from 1972 to 2010 using Johansen Co-integration technique. Asghar et al. (2013) showed that money supply, lagged inflation and foreign inflation had positive impact on inflation in Pakistan while exchange rate had negative relation for the period from 1972 to 2010 .

Joiya and Shahzad (2013) explained positive relationship of gross domestic product and Food Exports while negative effect of food import and credit to agriculture sector on food prices in Pakistan for period from 1972 to 2010. Hossain and Islam (2013) investigated that M2 and interest rate had positive relationship with inflation while fiscal deficit and nominal exchange had a negative impression in Bangladesh. 


\section{DATA AND METHODOLOGY}

This section describes the data sources, data type, data range, specification of model, estimation technique and expected relationship.

\section{A. DATA DESCRIPTION}

The study considers time series annual data for the period from 1981 to 2013. Few reliable sources are consulted for collection of data like Economic Survey of Pakistan (2012 - 2013), Handbook of Statistics on Pakistan Economy 2010, World Development Indicators $(C D-R O M)$ and International Financial Statistics (CD - ROM). Log - log form of the equation is considered to have elasticities of price level with respect to various factors included in the study.

\section{B. MODEL SPECIFICATION}

As regards to objectives, the present study specifies following model to trace out the influence of electricity generation on inflation rate of Pakistan.

Inflation $=\mathrm{f}\{$ Exports,Electricity Generation Money Growth,ExternalDebt,Gross Domestic Product\}

The above functional form may also be written in the following equation carrying Consumer Price Index as representative of Inflation. All the variables are taken in natural log form just to show elasticities.

$$
\mathrm{CPI}=\beta_{0}+\beta_{1} \text { EXPT }+\beta_{2} \text { ELECG }+\beta_{3} \text { MONG }+\beta_{4} \text { EXTDT }+\beta_{5} \text { GDP }+\mu_{1}
$$

The variables used in the above equations may be explained in table 1 .

\section{Table 1: Variable Description}

\begin{tabular}{|c|c|c|c|}
\hline Variable & Description & $\begin{array}{c}\text { Unit of } \\
\text { Measurement }\end{array}$ & $\begin{array}{c}\text { Expected } \\
\text { Relationship }\end{array}$ \\
\hline CPI & Consumer Price Index & Price Index & Dependent Variable \\
\hline EXPT & $\begin{array}{l}\text { Exports of Goods and } \\
\text { Services }\end{array}$ & Million Rupees & Positive \\
\hline ELECG & Electricity Generation & $\mathrm{KWH}$ & Negative \\
\hline MONG & Money Supply & Million Rupees & Positive \\
\hline EXTDT & External Debt & Million Rupees & Positive \\
\hline GDP & $\begin{array}{l}\text { Gross Domestic } \\
\text { Product }\end{array}$ & Million Rupees & Positive \\
\hline$\beta_{\mathbf{i}}$ & \multicolumn{3}{|c|}{ Elasticity of CPI with respect to exogenous variables } \\
\hline$\gamma_{\mathrm{i}}$ & \multicolumn{3}{|c|}{ Elasticity of GDP Deflator with respect to exogenous variables } \\
\hline$\mu_{i}$ & \multicolumn{3}{|l|}{ Error Terms } \\
\hline
\end{tabular}

\section{METHODOLOGICAL DISCUSSION}


To estimate econometric results, the study applies following tests for reliable estimates.

1. Augmented Dickey Fuller - unit root test is applied to know stationary of variables. ARDL test may only be applicable in a case in which few variables are integrated of

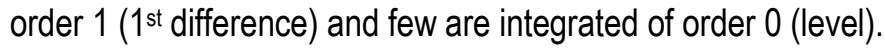

2. To apply ARDL test in the long run and short run, it is necessary to analyze long run relationship among variables using ARDL Bound testing approach in which restriction is applied using Wald Test and calculated values of F - Statistics are compared with critical values provided by Pesaran and Shin (1999) and Pesaran et al. (2001).

3. At third step, ARDL long run test is applied using Microfit 4.1 statistical software for long run elasticities of inflation with respect to various exogenous variables.

4. For ARDL short run, error correction model is run which provides error correction mechanism to show speed of adjustment.

5. For dynamic stability of estimates, the study employs CUSUM test and CUSUM SQUARE test.

\section{RESULTS AND DISCUSSIONS}

This section provides elaboration of econometric results which are conducted at various steps.

\section{A. AUGMENTED DICKEY FULLER TEST}

Table 2 provides us results of Augmented Dickey Fuller test for examining stationary of variables used in the study. It reports that Consumer Price Index, GDP Deflator, Exports of Goods and Services and Gross Domestic Product are stationary at $1^{\text {st }}$ differences while Electricity Generation, Money Supply and External Debt are stationary at their levels.

\section{B. ECONOMETRIC RESULTS}

ARDL requires the analysis of long run relationship among variables using Bound testing approach. $\mathrm{F}$ - Statistics value that is calculated through bound testing procedure is 6.21 which is greater than the critical as provided in Pesaran et al. (1999). It confirms the existence of long run association among variables used in the study. Next step requires 
estimation of long run and short run estimates using ARDL technique as results are presented in table 3 and 4 respectively.

Table 2: Unit Root Test

\begin{tabular}{|c|c|c|c|c|c|c|}
\hline Variables & $\begin{array}{l}\text { Unit root } \\
\text { test in }\end{array}$ & $\begin{array}{c}\text { Include } \\
\text { test }\end{array}$ & $\begin{array}{c}\text { ADF } \\
\text { Statistic }\end{array}$ & $\begin{array}{l}\text { Critical } \\
\text { Value }\end{array}$ & Prob. & Result \\
\hline \multirow{3}{*}{$\begin{array}{l}\text { Consumer } \\
\text { Price Index }\end{array}$} & & Intercept & 0.29 & -3.64 & 0.79 & \multirow{3}{*}{$\mathrm{I}(1)$} \\
\hline & Level & $\begin{array}{l}\text { Trend \& } \\
\text { Intercept }\end{array}$ & -0.30 & -4.26 & 0.66 & \\
\hline & $1^{\text {st }}$ Difference & Intercept & -4.12 & -3.65 & 0.00 & \\
\hline $\begin{array}{l}\text { Electricity } \\
\text { Generation }\end{array}$ & Level & Intercept & -4.19 & -3.64 & 0.00 & $\mathrm{I}(0)$ \\
\hline \multirow{3}{*}{ Export } & & Intercept & -2.06 & -3.64 & 0.25 & \multirow{3}{*}{$\mathrm{I}(1)$} \\
\hline & Level & $\begin{array}{l}\text { Trend \& } \\
\text { intercept }\end{array}$ & -1.99 & -4.26 & 0.58 & \\
\hline & $1^{\text {st }}$ Difference & Intercept & -5.29 & -3.64 & 0.00 & \\
\hline $\begin{array}{l}\text { Money } \\
\text { Supply }\end{array}$ & Level & Intercept & -4.77 & -3.64 & 0.00 & $\mathrm{I}(0)$ \\
\hline \multirow[b]{2}{*}{$\begin{array}{l}\text { External } \\
\text { Debt }\end{array}$} & \multirow[b]{2}{*}{ Level } & Intercept & -0.90 & -3.64 & 0.77 & \multirow[b]{2}{*}{$\mathrm{I}(0)$} \\
\hline & & $\begin{array}{l}\text { Trend \& } \\
\text { Intercept }\end{array}$ & -4.50 & -4.26 & 0.00 & \\
\hline \multirow{3}{*}{$\begin{array}{l}\text { Gross } \\
\text { Domestic } \\
\text { Product }\end{array}$} & & Intercept & -1.84 & -3.65 & 0.35 & \multirow{3}{*}{$\mathrm{I}(1)$} \\
\hline & Level & $\begin{array}{l}\text { Trend \& } \\
\text { Intercept }\end{array}$ & -1.99 & -4.27 & 0.58 & \\
\hline & $1^{\text {st }}$ Difference & Intercept & -3.60 & -3.65 & 0.011 & \\
\hline
\end{tabular}

Note: All variables are in natural log form.

Electricity generation exerts negative pressure on inflation of Pakistan with statistically significant coefficient value. It suggests that inflation of Pakistan will fall by 0.55 percent due to 1 percent higher electricity generation on the average in the long run. Higher electricity generation may be a cause of cheaper production of electricity. Electricity is considered as major input when determining price of any product. If input price will fall so ultimately, it will affect overall price level of the economy obviously. Elasticity of price level with respect to electricity generation is -0.55 in the long run.

Higher export is termed as increasing factor for price level of any economy through demand side as it raises demand for goods and services in foreign countries. Coefficient for exports is 0.46 suggesting 0.46 percent higher price level of Pakistan due to 1 percent higher exports in the long run on the average. The coefficient is also statistically significant at 5 percent level of significance. Elasticity of price level with respect to exports is 0.46 in the long run.

The study reveals positive impression of Gross Domestic Product on price level of Pakistan in the long run. Statistically, the coefficient value is not significant leaving 
importance of this variable in the study. On the other side, money supply is of great importance in determining price level of economy according to Quantity Theory of Money. According to economic theory, the same conclusion is drawn in the econometric results with positive and significant coefficient value. On the average, 1 percent higher money supply may be a cause of 0.66 percent higher price level of the economy. Elasticity of price level with respect to money supply is 0.66 in the long run.

In the study, External debt is turned out to be positive for consumer price index of Pakistan in the long run. The coefficient value is 0.50 and its probability value is 0.00 showing that 1 percent higher external debt of Pakistan may increase inflation by 0.50 percent on the average. It is due to increase in non-development expenditure which occurs usually whenever economy is doing deficit financing through external sources. It puts aggregate demand of the economy above aggregate supply according to Demand Pull Inflation. Elasticity of price level with respect to external debt is 0.50 in the long run.

Table 3: ARDL Long Run Model

\begin{tabular}{lcccc}
\hline Regressors & Coefficient & Standard Error & t-ratio & Probability \\
\hline ELECG & -0.55935 & 0.13746 & -4.0690 & 0.001 \\
\hline EXPT & 0.46529 & 0.21741 & 2.1402 & 0.044 \\
\hline GDP & 0.55762 & 0.46985 & 1.1868 & 0.248 \\
\hline MONG & 0.66354 & 0.11256 & -5.8949 & 0.000 \\
\hline EXTRDT & 0.50322 & 0.058746 & 8.5661 & 0.000 \\
\hline Constant & -4.3502 & 1.7510 & -2.4845 & 0.021 \\
\hline
\end{tabular}

Table 4: ARDL Short Run

\begin{tabular}{lcccc}
\hline Regressors & Coefficient & Standard error & t-ratio & probability \\
\hline ELECG & 0.16196 & 0.22494 & 0.72002 & 0.478 \\
\hline EXPT & 0.22779 & 0.099743 & 2.2838 & 0.031 \\
\hline MONG & -0.13326 & -0.052701 & 2.5286 & 0.018 \\
\hline EXTDT & 0.10784 & 0.044583 & 2.4188 & 0.023 \\
\hline GDP & 0.27299 & 0.25300 & 1.0790 & 0.291 \\
\hline ECM(-1) & -0.48956 & 0.11126 & -4.4002 & 0.000 \\
\hline DC & -2.1297 & -1.0720 & 1.9866 & 0.058 \\
\hline R-squared & 0.58647 & DW-statistic & 2.3110 \\
\hline F-statistics & 5.20 & Prob (F - Statistics) & 0.001 \\
\hline \multicolumn{5}{l}{}
\end{tabular}

ARDL short run results are presented in table 4 . These results portray that electricity generation, exports, external debt and gross domestic are found causes of higher inflation while money growth is found as reliable cause of higher inflation in Pakistan in the short run. Error correction mechanism (ECM) is revealed to be negative justifying convergence towards long run equilibrium due to any disequilibrium in the short run. 


\section{DYNAMIC STABILITY}

CUSUM and CUSUM SQUARE tests are utilized to see dynamic stability of ARDL results. ARDL model is considered as dynamically stable if estimated line (blue color) lies in critical lines (green \& purple line) as shown in figure 1 and 2 which confirms the stability of regression model in dynamic sense.

\section{Figure 1: CUSUM test}

Plot of Cumulative Sum of Recursive Residuals

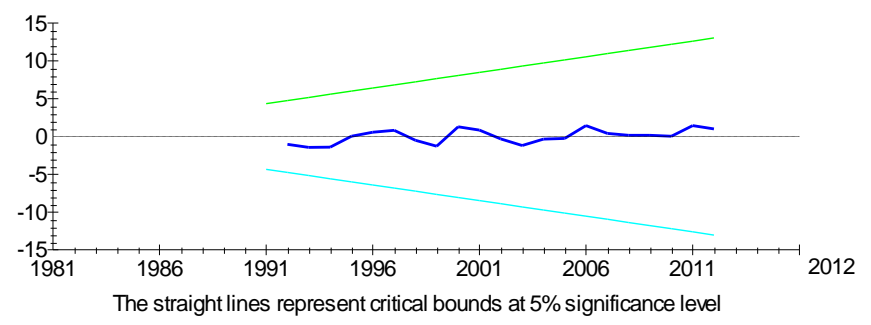

Figure 2: CUSUM SQUARE test

Plot of Cumulative Sum of Squares of Recursive Residuals

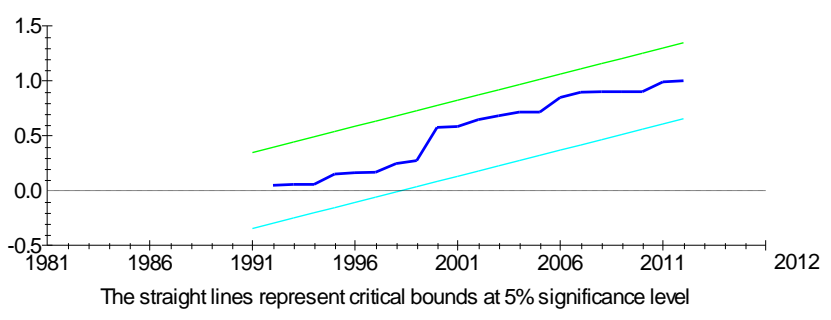

\section{CONCLUSIONS AND POLICIES}

Electricity generation plays an important role in maintaining price level of the economy over longer period of time. The study is aimed at investigating the effectiveness of Electricity Generation on Price level of Pakistan. For that purpose, time series annual data ranging from 1981 to 2013 is collected through various reliable sources and results are estimated using ARDL bound testing approach. Log - log form of the equation is utilized to have elasticities of price level with respect to various factors included in the study. 
The long run results of ARDL states that Electricity generation is a significant and contribute negatively in inflation. Exports of goods and services, gross domestic product, money supply and external debt are turned out to be motivating factor for higher price level of the economy. The Elasticity of Price Level with respect to Electricity Generation, Exports, GDP, Money Supply and External Debts are respectively - 0.55, 0.46, 0.55, 0.66, and 0.50. In the short run, error correction term suggests convergence towards long run equilibrium due to any disturbance occurring in the short run. On the basis of above results, it is suggested that price stability in the economy may be ensured through higher electricity production by domestic resources.

\section{REFERENCES}

Adom, K. P. (2011). Electricity Consumption Economic Growth Nexus: The Ghanaian Case. International Journal of Energy of Economic and Policy, 1(1), 18 - 31.

Asghar, N., Jaffri, A. A. and Asjed, R. (2013). An Empirical Investigation of Domestic and External Determinants of Inflation in Pakistan. Pakistan Economic and Social Review, 51 (1), $55-70$.

Aslan, A. Kum, H., Ocal, O. and Gozbasl, O. (2013). Energy Consumption and Economic Growth: Evidence from Micro Data. Proceedings of ASBBS, 20(1), 280 - 288.

Asteriou, D. (2005). Applied Econometrics: A modern approach using EViews and Microfit, Palgrave Macmillan.

Bashir, F. and Nawaz, S. Yasin, K., Khursheed, U., Khan, J. and Qureshi, M. J. (2011). Determinants of Inflation in Pakistan: An Econometric Analysis using Johansen CoIntegration Approach. Australian Journal of Business and Management Research, 1 (5), 71-82.

Bayo, F. (2009). Determinants of Inflation in Nigeria: An Empirical Analysis. International Journal of Humanities and Social Science, 1 (18), 262-271.

Bayraktutan, Y., Yılgör M. and Uçak, S. (2011), Renewable Electricity Generation and Economic Growth: Panel data Analysis for OECD Members, International Research Journal of Finance and Economics, 66, 59-67.

Dickey, D. A. and Fuller, W. A. (1979). Distribution of the estimators for autoregressive time series with a unit root. Journal of the American Statistical Association, 74, 427 431.

Domac, I. and Elbirt, C. (2010). The Main Determinants of Inflation in Albania. Unpublished, $1-39$.

Govt. of Pakistan (2000). 50 years of Pakistan in Statistics, Federal Bureau of Statistics, Statistical Division. 
Govt. of Pakistan (2011). Handbook of Statistics on Pakistan Economy 2010, State Bank of Pakistan.

Govt. of Pakistan (2012-13). Economic Survey of Pakistan, Federal Bureau of Statistics, Statistical Division.

Gujarati, D. N. and Porter, D. C. (2009). Basic Econometrics, $5^{\text {th }}$ Edition.

Hossain, T. and Islam, N. (2013). An Economic Analysis of the Determinants of Inflation in Bangladesh. The International Journal of Social Science, 11(1), 29 36.

Joiya, S. A. and Shahzad, A. A. (2013). Determinants of High Food Prices: The Case of Pakistan. Pakistan Economic and Social Review, 51 (1), 93-107.

Khan, A. A., Ahmed, Q. M. and Hyder, K. (2007). Determinants of Recent Inflation in Pakistan. Research Report No. 66, 1- 16.

Laryea, S. A. and Sumaila, U. R. (2001). Determinants of Inflation in Tanzania. WP 2001:12, 1-17.

Lim, C. H. and Papi, L. (2006). An Econometric Analysis of the Determinants of Inflation in Turkey. WP/97/170, 1 - 33.

Masuduzzaman, M. (2012). Electricity Consumption and Economic Growth in Bangladesh: Co-Integration and Causality Analysis. Global Journal of Management and Business Research, 12 (11), 46 - 56.

Morimoto, R. and Hope, C. (2004). The Impact of Electricity Supply on Economic Growth in Sri Lanka. Energy Economics, 26(1), 77 - 85.

Pesaran, H. M. and Shin, Y. (1999). Autoregressive Distributed Lag Modelling approach to Cointegration Analysis. Econometrics and Economic Theory in the 20th Century: The Ragnar Frisch Centennial Symposium (Cambridge: Cambridge University Press).

Pesaran, M. H., Shin, Y. and Smith, R. J. (1999). Structural analysis of vector error correction models with I(1) exogenous variables. Department of Applied Economics Working Paper, University of Cambridge.

Pesaran, M. H., Shin, Y. and Smith, R. J. (2001). Bound testing approaches to the analysis of level relationships. Journal of Applied Econometrics, 16, $289-326$.

Razzaqi, S., Bilquees, F. and Sherbaz, S. (2007). Dynamic Relationship between Energy and Economic Growth: Evidence from D8 Countries. The Pakistan Development Review, 50 (4), 437 - 458.

Sarker, R. and Alam, K. (2010). Nexus between Electricity Generation and Economic Growth in Bangladesh. Asian Social Science, 06(12), 16 - 22.

Shahbaz, M. and Feridum, M. (2012). Electricity Consumption and Economic Growth: Empirical Evidence from Pakistan. Quality and Quantity, 46 (5), 1583 - 1599.

World Bank, (2013). World Development Indicators. World Bank, Washington, DC. 